\title{
PENGELOLAAN RUANG KELAS DALAM RANGKA MENINGKATAN KEEFEKTIFAN PEMBELAJARAN DI PKBM INSAN CENDIKIA
}

\author{
Heni Mularsih ${ }^{1}$ Hartini $^{2}$, \\ ${ }^{1}$ Psikologi, Universitas Tarumanagara Jakarta \\ henim@mku.untar.ac.id \\ ${ }^{2}$ Jurusan Desain Interior, Universitas Tarumanagara Jakarta \\ hartini@fsrd.untar..ac.id
}

\begin{abstract}
ABSTRAK
Pengelolaan ruang kelas yang baik dapat berdampak pada pembelajaran efektif. Namun, Pengelolaan ruang kelas yang belum ideal masih ditemui di berbagai lembaga pendidikan nonformal, yang salah satunya adalah PKBM Insan Cendikia. Permasalahan yang ditemui di PKBM Insan cendikian tampak dalam (1) Ketidakpahaman pengelolan PKBM tentang kaitan antara pengelolaan kelas yang baik dan nyaman dengan pembelajaran yang efektif dan (2) Kurangnya kemampuan pengelola untuk menciptakan kondisi ruang kelas dengan area terbatas menjadi ruang kelas yang baik, tertata rapi, dan nyaman dengan memanfaatkan fasilitas yang ada dan pengembangannya. Dengan demikian, tujuan Tim melakukan kegiatan pengabdian kepada masyarakat adalah untuk membantu pengelolaan ruang kelas yang baik sehingga proses pembelajaran menjadi nyaman dan bagus/estetik.
\end{abstract}

Sebagai bentuk kepedulian Tim PKM kepada lembaga pendidikan nonformal (PKBM) untuk mengatasi permasalahn dialami, solusi yang diberikan yaitu melalui (1) sosialisasi dengan ceramah tentang pentingnya pengelolaan kondisi ruang kelas yang nyaman dan (2) melakukan perancangan dan implementasi perbaikan kondisi pengelolaan ruang kelas yang baik. Target kegiatan PKM yang dilakukan (1) terkait dengan sosialisasi yaitu adanya pemahaman tentang pentingnya mengelola fasilitas yang ada dan pengembangannya yang diaplikasikan pada pengelolaan kelas yang baik dan nyaman bagi warga belajar maupun tutor sehingga menunjang terciptanya pembelajaran yang efektif dan (2) terkait dengan implentasi lay out pada ruang kelas pada area terbatas yaitu terciptanya kondisi ruang kelas yang rapi dan nyaman sehingga pembelajaran menjadi lebih efektif. Luaran kegiatan PKM adalah: (1) Pemahaman baru tentang perlunya mengelola fasilitas yang ada dan pengembangannya dan (2) Kondisi ruang kelas yang tertata dengan rapi sehingga nyaman sebagai penunjang terciptanya pembelajaran yang efektif.

Kata kunci: sosialisasi, PKBM, pengelolaan kelas, efektivitas pembelajaran

\section{PENDAHULUAN}

Untuk menciptakan suasana kondisi yang dapat menumbuhkan minat, semangat dan motivasi siswa dalam mengikuti pembelajaran dalam pembelajaran yang efektif diperlukan pengorganisasian atau pengelolaan yang memadai, termasuk dalam pengelolaan kelas (Zulfiani, 2009).

Pengelolaan kelas menjadi penting karena kelas merupakan lingkungan belajar utama yang dapat diciptakan berdasarkan kesadaran kolektif dari suatu komunitas siswa yang relatif memiliki tujuan yang sama. Kesamaan tujuan merupakan kekuatan potensial pengelolaan kelas dan aktualitasnya adalah proses pembelajaran yang akseptabel (Fathurohman, 2007). Dengan demikian, pengelolaan kelas menjadi salah satu sara yang menyiapkan kondisi bagi pembelajaran yang efektif. Pengelolaan kelas mencakup pada pengaturan orang (siswa) dan fasilitas yang meliputi, ventilasi, pencahayaan sampai dengan pereancangan program pembelajaran yang tepat. "Pengelolaan kelas atau organisasi kelas meliputi berbagai komponen, yakni guru, siswa, dan lingkungan fisik. Ketiga aspek tersebut saling berinteraksi untuk menciptakan aktivitas pembelajaran di kelas yang kondusif dan aman" (Zulfani, 2009: 162) 
Pengelolaan kelas menjadi penting karena kelas merupakan lingkungan belajar utama yang dapat diciptakan berdasarkan kesadaran kolektif dari suatu komunitas siswa yang relatif memiliki tujuan yang sama. Kesamaan tujuan merupakan kekuatan potensial pengelolaan kelas dan aktualitasnya adalah proses pembelajaran yang akseptabel (Fathurohman, 2007). Dengan demikian, pengelolaan kelas menjadi salah satu sara yang menyiapkan kondisi bagi pembelajaran yang efektif. Pengelolaan kelas mencakup pada pengaturan orang (siswa) dan fasilitas yang meliputi, ventilasi, pencahayaan sampai dengan pereancangan program pembelajaran yang tepat. "Pengelolaan kelas atau organisasi kelas meliputi berbagai komponen, yakni guru, siswa, dan lingkungan fisik. Ketiga aspek tersebut saling berinteraksi untuk menciptakan aktivitas pembelajaran di kelas yang kondusif dan aman" (Zulfani, 2009: 162).

Namun, kenyataannya belum semua pengelola di lembaga pendidikan mampu melakukan pengelolaan kelas dengan baik. Kenyataan ini juga dialami oleh PKBM Insan Cendikia. Kondisi ukuran ruang kelas memiliki area yang terbatas, dengan fasilitas yang terbatas pula, dan penataan fasilitas yang seadanya. Pengelola belum memiliki pemahaman tentang pentingnya penataan ruang kelas yang baik sehingga dapat berdampak pada aktivitas pembelajaran. Selain itu, pengelola juga belum mampu mengelola kelas yang ideal dengan memanfaatkan fasilitas yang ada dan pengembangannya. Gambaran kondisi permasalahan yang tercakup dalam aspek manajemen usaha meliputi: (1) ketidakpahaman pengelolan PKBM tentang kaitan antara pengelolaan kelas yang baik dan nyaman dengan pembelajaran yang efektif (2) Kurangnya kemampuan pengelola untuk menciptakan kondisi ruang kelas dengan area terbatas menjadi ruang kelas yang baik, tertata rapi, dan nyaman dengan memanfaatkan fasilitas yang ada dan pengembangannya. Dengan demikian, tujuan Tim melakukan kegiatan pengabdian kepada masyarakat adalah untuk membantu pengelolaan ruang kelas yang baik sehingga proses pembelajaran menjadi nyaman dan bagus/estetik

\section{METODE PELAKSANAAN PKM}

\section{a. Sosialisasi}

\section{Pengumpulan Data PKM}

Wawancara mitra terkait Pengelolaan Fasilitas Ruang Kelas yang bermanfaat untuk mengefektifkan pembelajaran. Team PKM melakukan wawancara, pengamatan pada pengelola fasilitas sekolah memiliki pengetahuan yang cukup tentang pengelolaan yang baik untuk menunjang keefektifan pembelajaran. Selain itu, pengelola fasilitas yang ada berkaitan dengan pengelolaan kelas. Berdasarkan pengumpulan data baik wawancara, maupun pengamatan, perlu tata ruang kelas/pengelolaan fasilitas kelas yang baik dan nyaman karena berpengaruh dalam mengefektifkan proses belajar mengajar. Untuk kelanjutannya, pengelolaan fasilitas ruang kelas yang baik berdampak pada aktivitas guru dan siswa dalam belajar mengajar menjadi bersemangat. Berkaitan dengan pencapaian tujuan untuk mengoptimalkan pembelajaran yang efektif, materi pengumpulan data tentang pengelolaan kelas meliputi (1) jenis aktivitas yang dilakukan di dalam kelas, (2) fasilitas-fasilitas yang mendukung aktivitas, dan (3) pengguna dalam ruang kelas tersebut berserta karakteristiknya

\section{Menganalisis terkait Pengelolaan Fasilitas Ruang Kelas}

Dalam kegiatan analisis ini, aktivitas yang dilakukan oleh tim adalah mengolah fasilitas di ruang kelas meliputi elemen interior yaitu dinding dan plafond, dengan mengikuti langkah-langkah berikut. Langkah tersebut adalah: (1) Observasi kondisi dan fasilitas yang ada, (2) Mendata kegiatan pembelajaran para pengguna, (3) Mendata fasilitas yang ada di ruang kelas, (4) Mengkaji 
kebutuhan aktivitas dan fasilitas ruang, dan (5) Menganalisis permasalahan yang dihadapi oleh pengguna (guru dan murid).

\section{a. Implementasi Perancangan Elemen Interior Ruang Kelas}

Aspek yang mempengaruhi "Pengelolaan kelas atau organisasi kelas meliputi berbagai komponen, yakni guru, siswa, dan lingkungan fisik. Ketiga aspek tersebut saling berinteraksi untuk menciptakan aktivitas pembelajaran di kelas yang kondusif dan aman" (Zulfani, 2009: 162).

Berdasarkan pernyataan di atas, lingkup pengelolaan kelas dalam kegiatan PKM ini dibatasi untuk bidang penataan lingkungan fisik (fasilitas yang berkaitan dengan ruang kelas, yaitu dinding, plafond dan seting fisik furniture). Langkah tersebut adalah: (1) Membuat konsep desain yang diharapkan, (2) Menentukan pedoman desain. , (3) Implementasi produksi, dan (4) Evaluasi hasil implementasi rancangan

\section{HASIL DAN PEMBAHASAN}

\section{a. Kegiatan Sosialisasi \\ Pengumpulan Data PKM}

\begin{tabular}{cll}
\hline No. & \multicolumn{1}{c}{ Rencana Kegiatan } & \multicolumn{1}{c}{ Aktivitas } \\
\hline 1 & $\begin{array}{l}\text { Observasi kondisi dan fasilitas } \\
\text { ruang kelas yang ada di PKBM }\end{array}$ & Mitra menerima gagasan \\
\hline 2 & $\begin{array}{l}\text { Mendata kegiatan para } \\
\text { pengguna. }\end{array}$ & $\begin{array}{l}\text { Mitra menjelaskan kegiatan } \\
\text { pengguna }\end{array}$ \\
\hline 3 & $\begin{array}{l}\text { Mendata fasilitas yang ada di } \\
\text { ruang kelas }\end{array}$ & $\begin{array}{l}\text { Mitra menjelaskan kondisi ruang } \\
\text { berserta inventaris fasilitas yang } \\
\text { dimiliki }\end{array}$ \\
\hline
\end{tabular}

Pengumpulan data berikutnya dengan studi literatur dan pustaka, hal ini untuk analisis data berikutnya.

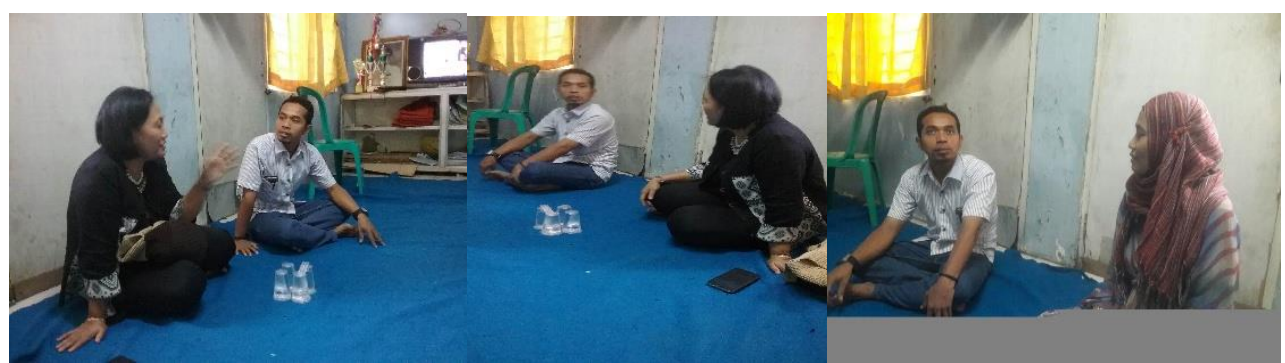

Gambar 1. Proses kegiatan sosialisasi kepada Pengelola PKM

Hasil sosialisasi yaitu adanya peningkatan pemahaman dari pihak pengelola, yang awalnya kurang memahami pentingnya penelolaan kelas terkait dengan pengelolaan fasilitas maupun pengembangannya menjadi paham bahwa pengelolaan kelas yang baik akan dapat memengaruhi aktivitas pembelajaran. Tolok ukur adanya peningkatan pemahaman berwal dari pemikiran awal yang kurang memperhatikan kondisi ruang kelas yang kurang rapi bahkan penataan tempat duduk yang tidak rapi di lokasi kelas sempit menjadi bahwa penataan ruangan kelas yang baik dan rapi sehingga nyaman itu merupakan hal yang penting. Adanya pemahaman ini ditunjukkan dengan perilaku menyambut dengan baik pada kedatangan TIM dan para tukang. Selain itu, pihak 
pengelolah juga menunjukkan perilaku antusias ketika diajak berdiskusi mengenai tata letak fasilitas di ruang kelas.

Tolok ukur berikutnya yang menunjukkan bahwa pemahaman pengelola PKBM tentang pengelolaan kelas meningkat, yaitu menjadi sadar untuk melakukan sendiri pengecatan bagian ruangan lain yang belum dicat oleh Tim PKM.Pengecatan dilakukan setelah kegiatan Tim PKM selesai.

\section{b. Kegiatan Implementasi Proses Disain dan Pelaksanaan Pengelolaan Kelas}

\section{Kondisi Awal}

Spesifikasi model yang ditawarkan berupa lay ot dan implementasi tata ruang kelas dan cara pengaturan furniture dengan menerapkan teori desain interior yang ideal. Pembuatan desain interior ruang kelas dilakukan melalui program pendampingan dengan mitra. Pembuatan desain dilakukan pada dua tempat, yaitu di ruang kelas A dan kelas B, sehingga konsumen merasa nyaman saat mengikuti pelatihan dan ketrampilan. Desain kedua yang dilakukan yaitu membuat implementasi elemen interior di kelas-kelas tersebut. Hal ini dilakukan agar mitra dapat juga melakukan kegiatan belajar mengajar.

Model desain yang ditawarkan kepada mitra yaitu menghasilkan pengolahan elemen interior pada ruang kelas yang nyaman, meliputi: pengolahan dinding, penataan lay out kelas, karpet kelas. Proses kegiatan desain tersebut terdiri dari beberapa langkah yaitu:

\section{1) Pengolahan Dinding}

Penyediaan alat dan bahan yang diperlukan alat dan bahan yang diperlukan meliputi: (a) Cat dinding, (b) Rol, (c) Finir, (d) Lem, dan (d) Sealants
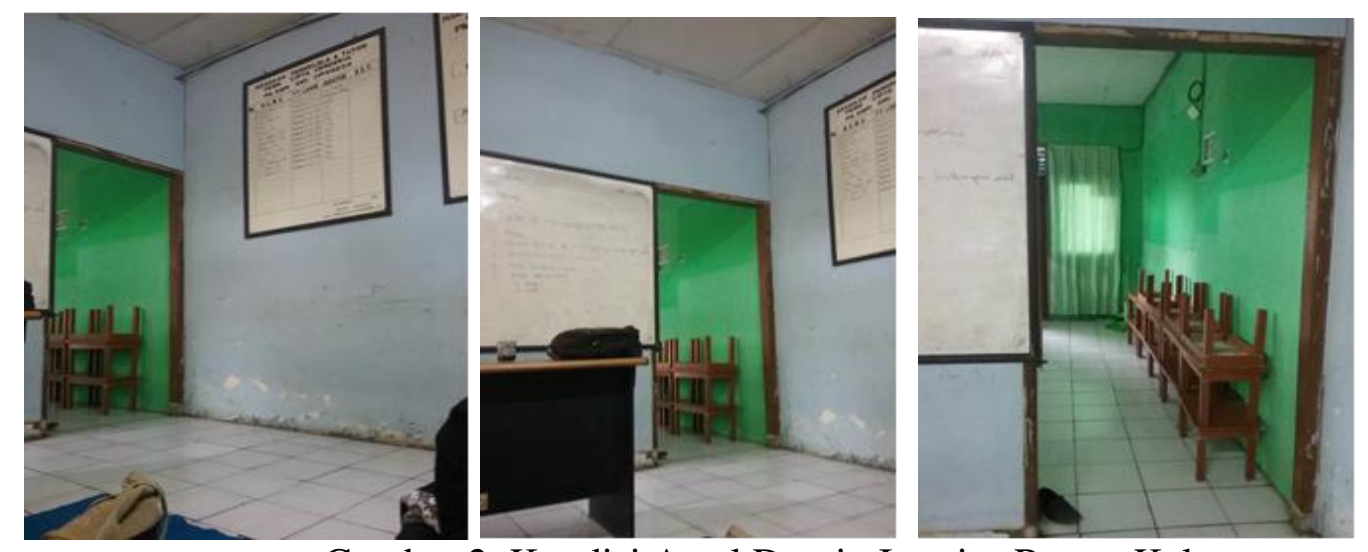

Gambar 2. Kondisi Awal Desain Interior Ruang Kelas

2) Proses desain kelas (langkah-langkah pembuatan)

Konsep layout kelas, mengikuti langkah-langkah sebagai berikut : (a) Membuat organisasi ruang, (b) Pengoloahan elemen interior kelas, dan (c) Tahap finishing Elemen interior yang telah diimplementasikan tersebut diperiksa dan diberi amplas ulang di bagian-bagian yang diperlukan. Hal tersebut bertujuan untuk mencegah adanya dinding yang tidak rata. Fifinshing penataan layout furniture juga menjadi perhatian dengan menyesuaiakan ukuran ergonomic yang standar. Gambaran pengerjaan pengecatan ruang kelas tampak pada gambar-gambar di bawah ini. 


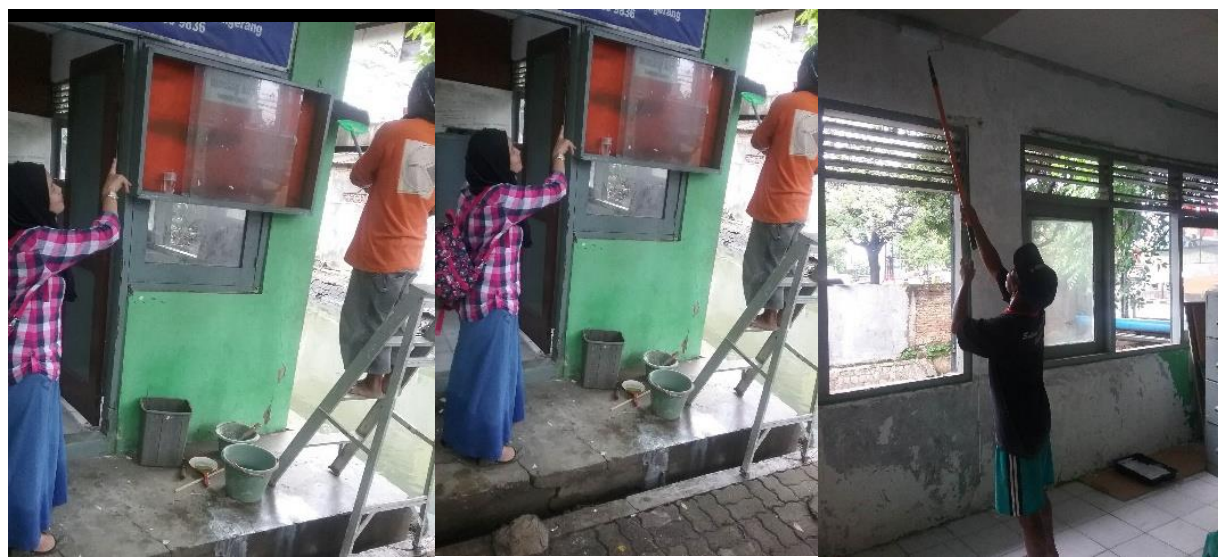

Gambar 3. Persiapan dan Pelaksanaan Desain Interior Ruang Kelas

\section{Kondisi Akhir Setelah Pelaksanaan Desain Interior Ruang Kelas}

Setelalah dilakukan implementasi desain interior ruang kelas dengan mengikuti langkah-langkah sesuai dengan yang dituliskan di atas, dihasilkan kondisi ruang kelas yang indah dan nyaman dengan warna cat diding yang terang dan tampak bersih di bagian atas karena bercat putih dan bawah warna hijau tua/warna gelap sehingga tidak tampak jorok.

Setelah selesai pelaksanaan pengecatan dinding ruang kelas, mitra (pengelola PKBM) tampak senang dengan mengucapkan banyak terima kasih. Sebenarnya pihak mitra masih mengharapkan adanya bantuan lagi, yang tidak sekedar pada pagian pengecatan dan seting ruang kelas. Hal ini dapat dimaklumi mengingat kondisi lain juga masih memprihatinkan. Kondisi ruang kelas, kusen jendela dan pintunya sudah mulai rapuh memang sudah sangat using. Kondisi ini memang tidak cukup jika hanya dengan pengecatan karena kondisi kusen juga sudah rapuh semua. Dengan demikian, sebenarnya masih perlu dana tambahan yang jauh lebih besar untuk membuat kondisi ruang kelas yang indah dan nyaman secara keseluruhan sehingga diperlukan kegiatan PKM lanjutan.

Kondisi akhir setelah selesai pelaksanaan pengecatan dinding ruang kelas, tampak pada gambargambar di bawah ini.

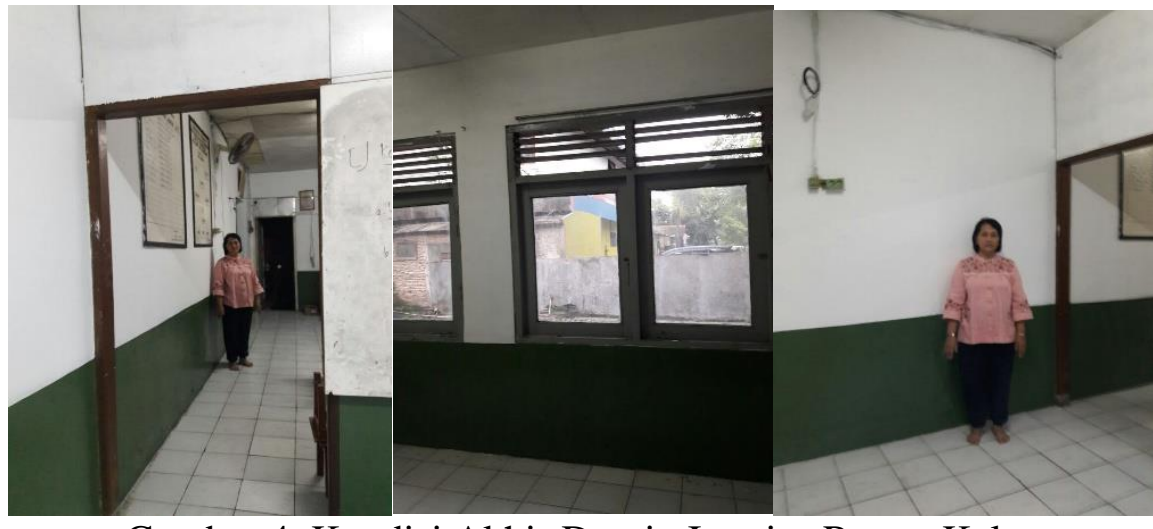

Gambar 4. Kondisi Akhir Desain Interior Ruang Kelas

(Dokumen pribadi) 


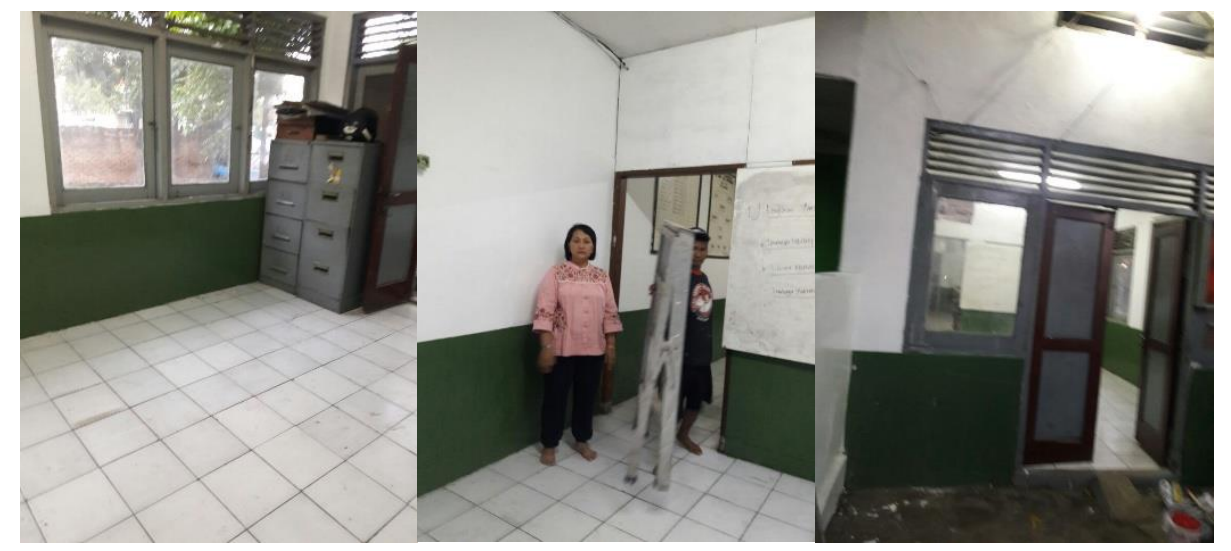

Gambar 5. Kondisi Akhir Desain Interior Ruang Kelas

(Dokumen pribadi)

\section{Tahap Evaluasi}

Untuk mengetahui keberhasilan kegiatan PKM yang dilakukan, perlu dilakukan evaluasi untuk melihat Setelah kegiatan sosialisasi.

a. Kondisi cat di dinding ruang kelas

Namun, kondisi cat yang di dinding sudah banyak yang mengelupas dan dinding tampak kotor. Setelah dilakukan redesain interior ruangan, dengan cara dicat ulang. Setelah pengecatan selesai, respon dari warga belajar yang menjawab baik/halus melekat di dinding sebanyak 26 orang ( $87 \%$ ), biasa sebanyak 4 orang $(13 \%)$, dan yang menjawab tidak baik (terkelupas) sebanyak 0 orang $(0 \%)$.

b. Warna ruangan

Pada kondisi awal, ruang kelas bercat hijau muda dan abu-abu muda. Warna cat sudah mulai pudar dan tampak kotor. Kemudian, warna cat diperbarui. Cat dinding berwarna kombinasi bawah berwarna hijau tua agar tidak mudah kotor, dan atasnya berwarna putih agar tampak bersih. Setelah pengecatan selesai respon dari 30 warga belajar yang menjawab menarik sebanyak 22 orang ( $73 \%$ ), yang menjawab biasa 6 orang (20\%), yang menjawab tidak menarik sebanyak 2 orang ( $7 \%$ ).

c. Tata letak tempat duduk

Sebelum dilakukan sosialisasi, terdapat beberapa kursi di ruang kelas, ada meja pendek untuk menulis di dalam kelas. Setelas dilakukan sosialisasi dan penetaan ruangan, kursi-kursi ditaruh di ruangan lain, ruang kelas hanya digelari karpet dan meja pun juga disingkirkan jika jumlah warga belajar banyak, terutama pembelajaran menjelang ujian. Penataan tersebut membuat ruangan menjadi lebih lega jika dinandingkan dengan adanya kursi-kursi masih ada di ruang kelas. Berdasarkan penataan tersebut, respon warga belajar yaitu yang menjawab rapi 26 orang ( $87 \%$ ), yang menjawab biasa, sebanyak 4 orang ( $13 \%)$, dan menjawab tidak rapi sebanyak 0 orang ( $0 \%)$

d. Kondisi posisi duduk dalam kelas

Sebelum diadakan penataan seting tempat duduk, kondisi tempat duduk kurang teratur karena pada saat jumlah warga belajar yang datang sedikit, ada warga belajar yang duduk dengan bersandaran kursi dan ada yang tanpa sandaran kursi. Posisi kursi ada di dalam ruang kelas. Namun, setelah dilakukan penataan, posisi kursi dipinggirkan dan ditempatkan di ruangan lain, semua warga belajar duduk di lantai tanpa sandaran kursi sehingga ruangan menjadi lebih luas dan daya tamping menjadi lebih besar. Berdasarkan kondisi tersebut, respon warga belajar yang menjawab teratur dan nyaman sebanyak 24 orang ( $80 \%$ ), yang menjawab biasa sebanyak 6 orang ( $20 \%$ ), tidak teratur karena semuanya duduk di lantai tanpa sandaran di kursi, sebanyak 0 orang ( $0 \%)$

e. Kondisi saat berlangsung pembelajaran

Dari 30 warga belajar yang menjawab tenang sebanyak 21 orang ( $70 \%)$, yang menjawab biasa, sebanyak 3 orang ( $10 \%)$, yang menjawab berisik sebanyak 6 orang $(20 \%)$ 


\section{KESIMPULAN DAN SARAN}

\section{Kesimpulan}

Berdasarkan kegiatan PKM yang sudah dilaksanakan dapat disimpulkan sebagai berikut.

a. Pelaksanaan sosialisasi mengenai pengelolaan kelas berjalan dengan baik dan lancar.

b. Pelaksanaan pengolahan elemen interior telah berjalan baik.

c. Terjadi peningkatan pemahaman pada pengelola PKBM. Pemahaman tersebut terkait tentang pentingnya pengelolaan ruang kelas terkait dengan penataan fasilitas kelas dan pengecatan dinding ruang kelas

d. Terealisasinya pengelolaan kelas yang nyaman sehingga dapat membantu terciptanya pembelajaran yang efektif. Hal ini diperkuat adanya respon para warga belajar yang mengarah pada perlunya pengelolaan kelas yang baik melalui beberapa pernyataan dalam kuesioner yang mereka isi. Gambaran respon tersebut yaitu, (1) Kondisi cat di dinding ruang kelas baik/halus melekat di dinding sebanyak 26 orang (87\%), (2) warna ruangan setelah pengecatan direspon menarik oleh 22 orang ( $73 \%$ ), (3) tata letak tempat duduk di ruang kelas direspon menjadi lebih lega jika dibandingkan sebelum adanya penataan ulang direspon 26 orang $(87 \%)$, (4) Kondisi posisi duduk dalam ruang kelas direspon teratur oleh 24 orang ( $80 \%$ ), dan (5) kondisi saat berlangsung pembelajaran direspon tenang oleh 21 orang $(70 \%)$, yang menjawab biasa, sebanyak 3 orang $(10 \%)$, yang menjawab berisik sebanyak 6 orang $(30 \%)$

\section{Saran}

Berdasarkan hasil kerja kegiatan PKM yang sudah dilakukan, TIM PKM menyarankan kepada Mitra yang diwakili oleh Pengelola PKBM, yaitu:

a. Perlu melakukan penataan fasilitas yang ada di ruangan lain, misalnya ruang kantor yang kondisinya juga belum rapi. Hal ini menjadi penting agar kondisi menjadi nyaman, terutama ketika terjadi kegiatan pelayanan para warga belajar yang ingin memperoleh informasi di kantor.

b. Mengingar ukuran ruangan yann sempit, perlu pengaturan jadwal belajar agar bergantian untuk per Paketnya (Paket A, B, dan C yang selalu dipisahkan). Selama ini, ketiga paket terbit kadang-kadang masih dicampur saat pembelajaran.

\section{DAFTAR PUSTAKA}

Arikunto, Suharsimi. 1996. Pengelolaan Kelas dan Siswa. Jakarta: PT Grasindo.

Fathurohman, Pupuh. 2007. Strategi Belajar Mengajar: Strategi Mewujudkan Pembelajaran Bermakna melalui Penanaman Konsep Umum dan Konsep Islami. Bandung: PT Rafika Aditama.

Widyarani, Diana. 2011. Pengaruh Pengelolaan Kelas terhadap Pembelajaran Efektif pada $\begin{array}{lllll}\text { Mata Pelajaran } & \text { IPS } & \text { 29/7/ } & \end{array}$ http://repository.uinjkt.ac.id/dspace/DIANWIDYARANI-FITK.pdf.

Zulfani, dkk. 2009. Strategi Pembelajaran Sains. Jakarta: Lembaga Penelitian UIN Jakarta Zimmerer, T.W. Scarborough, N.M. \& Wilson, D. (2008). Essentials of Entrepreneirship and small business management, 5th edition, Pearson Education Inc, New Jersey 